\title{
PEMBELAJARAN MUSIK ANGKLUNG MELALUI \\ METODE HAND SIGN KODALY PADA SISWA TUNARUNGU DI SEKOLAH LUAR BIASA NEGERI CIAMIS
}

\author{
Ade Ani Sunartin \\ Prodi Sendratasik FKIP Universitas Muhammadiyah Tasikmalaya \\ Jln. Tamansari no. KM 2,5 Tasikmalaya \\ Email: adeanisunartin09@gmail.com \\ Denden Setiaji \\ Prodi Sendratasik FKIP Universitas Muhammadiyah Tasikmalaya \\ Jln. Tamansari no. KM 2,5 Tasikmalaya \\ Email: denden@umtas.ac.id
}

\begin{abstract}
The purpose of this study is this study aims to obtain data that are naturalistic and factual about learning Angklung music through the method of hand sign kodaly on deaf students in foreign schools in Ciamis. The data collection is done by observation, interviews, documentation, literature studies, data processing is done by compiling learning plans, learning steps, and the results of changes from the methods implemented. This research uses a descriptive method with a qualitative approach. Angklung music learning is an activity in learning that contains elements of developing students' basic skills in the field of music including intellectual, emotional, social, perceptual, physical, creativity, as well as having local wisdom values. Based on the analysis of angklung music learning through the Kodaly hand sign method, it turned out to be effectively applied in the Ciamis special foreign school, with very good student assessments of $50 \%$ or 10 students, $30 \%$ good students or 5 students, 20 sufficient students $\%$ or 4 students, and less students namely $10 \%$ or 1 student. Data obtained from this study in addition to the effectiveness of the method is also the author sees the ability of teachers to convey learning methods, the data is taken from observations of each meeting in class held in 4 meetings. So it can be concluded that the learning method used by the teacher in conveying angklung music material to deaf students is including the method of using the Indonesian signaling system (SIBI) and the Kodaly hand sign method.
\end{abstract}

\section{Keywords:}

angklung music learning, Kodaly hand sign, deaf students

\begin{abstract}
ABSTRAK
Tujuan dari penelitian ini adalah Penelitian ini bertujuan untuk memperoleh data data yang bersifat naturalistik dan factual tentang Pembelajaran musik angklung melalui metode hand Sign kodaly pada siswa tunarungu di sekolah luar biasa negeri Ciamis. Pengumpulan datanya dilakukan dengan teknik observasi, wawancara, dokumentasi, studi literatur, pengolahan datanya dilakukan dengan cara menyusun perencanaan pembelajaran, langkah - langkah pembelajaran, serta hasil perubahan dari metode yang dilaksanakan. Penelitian ini menggunakan metode deskriptif dengan pendekatan kualitatif. Pembelajaran musik angklung ini merupakan kegiatan dalam pembelajaran yang mengandung unsur pengembangan kemampuan dasar siswa di bidang musik meliputi kemampuan intelektual, emosional, sosial, perseptual, fisik, kreatifitas serta memiliki nilai nilai kearifan lokal. Berdasarkan hasil analisis pembelajaran musik angklung melalui metode hand sign Kodaly, ternyata efektif diterapkan di sekolah luar biasa negeri Ciamis, dengan penilaian siswa didik sangat baik yaitu 50\% atau 10 orang siswa, siswa didik baik $30 \%$ atau 5 orang siswa, siswa didik cukup 20\% atau 4 orang siswa, dan siswa didik kurang yaitu $10 \%$ atau 1 orang siswa. Data yang diperoleh dari penelitian ini selain keefektifan metode juga penulis melihat kemampuan guru dalam menyampaikan metode pembelajaran, data tersebut diambil dari pengamatan setiap pertemuan di kelas yang diadakan dalam 4 pertemuan. Maka dapat disimpulkan bahwa metode pembelajaran yang digunakan guru dalam menyampaikan materi musik angklung pada siswa tunarungu yaitu diantaranya dengan metode menggunakan sistem isyarat bahasa Indonesia (SIBI) dan metode hand sign Kodaly.
\end{abstract}

Kata Kunci:

pembelajaran musik angklung, hand sign Kodaly, siswa tunarungu.

\section{A. PENDAHULUAN}

Pendidikan budaya bisa menciptakan lingkungan belajar yang mengintegrasi pada proses pembelajaran yang mampu memahami konsep ilmu pengetahuan dalam bentuk pemikiran yang berkembang. Pendidikan budaya sebagai salah satu mata pelajaran yang diajarkan di sekolah formal karena dinilai bermanfaat terhadap kebutuhan perkembangan peserta didik untuk memberikan pengalaman estetika, kegiatan berekspresi, berkreasi dan berapresiasi juga berprestasi melalui pendekatan belajar dengan seni.
Pendidikan seni merupakan segala usaha untuk meningkatkan kemampuan kreatif, ekspresi siswa dalam mewujudkan kegiatan berkesenian. Pendidikan Seni memiliki peranan penting dalam pembentukan pribadi peserta didik dengan memperlihatkan kebutuhan perkembangan siswa dalam mencapai multi kecerdasan. Mata pelajaran seni budaya yang didalamnya memuat seni musik. Seni tari, seni rupa, dan teater yang merupakan salah satu mata pelajaran yang bisa membantu mengembangkan pengetahuan dan kreativitas siswa untuk membentuk kepribadian yang memiliki nilai 
estetika dan memahami perkembangan Seni Budaya Nasional.

Mata pelajaran Seni Budaya terkadang hanya dianggap sebelah mata dan dipandang kurang penting sehingga sering tersisih oleh mata pelajaran lain di dalam kurikulum. Menempatkan mata pelajaran Seni Budaya dan Keterampilan mendapat porsi yang kurang dan bisa dibilang tidak seimbang dengan mata pelajaran lain. Pemadatan materi terhadap pelajaran Seni Budaya mengakibatkan tidak sesuainya pelaksanaan dan pencapaian hasil tujuan awal pembelajaran. Seni yang akan diteliti dan dipelajari lebih dalam oleh penulis adalah seni musik.

Seni musik merupakan bagian yang tidak dapat dipisahkan dalam kehidupan manusia, untuk itu mata pelajaran seni musik sangat penting dilakssiswaan disekolah, selain untuk melestarikan budaya juga bisa dimaknai sebagai bagian dari kehidupan, seni musik bisa diterima semua kalangan tidak terkecuali siswa berkebutuhan khusus, seni musik adalah seni yang bisa diterima indera pendengaran. Pada dasarnya manusia dilahirkan memiliki hak seperti pada umumnya termasuk hak untuk mendapatkan pendidikan, siswa berkebutuhan khusu pun berhak mendapat pendidikan. Salah satu sekolah yang menangani siswa berkebutuhan khusus adalah SLBN Ciamis, mulai dari kelas A (Tunanetra), kelas B (Tunarungu), kelas $\mathrm{C}$ dan $\mathrm{C} 1$ (Tunagrahita ringan dan sedang), kelas D (Tuna Daksa ringan dan sedang).

Pembelajaran musik angklung di sekolah luar biasa negeri Ciamis dipersiapkan oleh guru bertujuan agar peserta didik mampu berinteraksi terhadap lingkungan sosial. Pembelajaran musik angklung sekolah ini, difokuskan untuk siswa kelas B yaitu kelas tunarungu, untuk itu perlu strategi tersendiri untuk mencapai tujuan pembelajaran.

\section{B. METODE PENELITIAN}

Desain penelitian merupakan rumusan dari rancangan rancangan dibuat agar penelitian jelas dan mencapai tujuan yang diharapkan. Dalam pelaksanaannya suatu penelitian harus ditentukan dengan metode yang akan digunakan terlebih dahulu sehingga penetapan metode penelitian akan memandu dan mengarahkan penelitian dalam melakukan penelitian.

Penelitian tentang pembelajaran musik angklung melalui metode hand sign kodaly pada siswa tunarungu di sekolah luar biasa negeri Ciamis ini menggunakan metode deskriptif analitik dengan pendekatan kualitatif. Penelitian ini bertujuan untuk memperoleh data data yang bersifat naturalistik dan faktual. Penelitian deskriptif adalah suatu jenis penelitian yang memiliki karakteristik menafsirkan dan menuturkan data yang bersangkutan dengan situasi yang sedang terjadi. Kegiatan penelitian ini meliputi pengumpulan data tentang perumusan masalah dan fokus terhadap pertanyaan penelitian, menganalisis data, menginterpretasi data dan diakhiri dengan sebuah kesimpulan hasil dari pembelajaran musik angklung melalui metode hand sign kodaly pada siswa tunarungu di sekolah luar biasa negeri Ciamis.

Metode kualitatif merupakan penelitian pengambilan sampel sumber data, yang digunakan untuk meneliti pada kondisi objek yang alamiah dimana peneliti adalah sebagai instrumen kunci, teknik pengumpulan dengan triangulasi, analisis data bersifat induktif/kualitatif, dan hasil penelitian kualitatif lebih menekankan makna daripada generalisasi. Dapat disimpulkan bahwa pendekatan kualitatif terpusat pada penelitian yang menjadi alat utama dalam mencari data yang akurat dan mencari data secara mendasar. Penelitian menilai bahwa pendekatan secara kualitatif akan membantu peneliti dalam mengumpulkan data dan mengetahui kualitas atau mutu dari pembelajaran yang dilaksanakan. Pemilihan metode ini digunakan untuk mengungkapkan tentang bagaimana gambaran proses pembelajaran musik angklung melalui metode hand sign kodaly pada siswa tunarungu di sekolah luar biasa negeri Ciamis.

\section{HASIL PENELITIAN PEMBAHASAN}

Berdasarkan hasil observasi dan wawancara yang di mulai tanggal 3 April sampai 6 Mei 2019 diperoleh data - data tentang pembelajaran musik angklung. Data - data yang ditemukan merupakan hasil wawancara dengan guru wali kelas Ibu Elpi Sukaesih. S.Pd dan siswa - siswi kelas Tunarungu sebagai partisipan dalam penelitian ini.

Penelitian pembelajaran musik angklung yang dilakukan, dengan desain dua putaran yaitu putaran pertama dimulai dengan metode isyarat bahasa Indonesia kemudian pembelajaran musik angklung dengan metode hand sign kodaly. Pada saat penelitian, pengamat mengisi lembar observasi kegiatan pembelajaran. Hal ini bertujuan untuk mengamati dan mengetahui kemampuan peneliti dalam melaksanakan kegiatan pembelajaran di kelas. Adapun yang menjadi pengamat dalam penelitian ini adalah wali kelas.

Setelah melakukan serangkaian penelitian pelaksanaan proses pembelajaran musik angklung melalui metode hand sign kodaly di SLB Negeri Ciamis, akhirnya diperoleh data hasil penelitian meliputi: (1) Rencana pelaksanaan pembelajaran musik angklung melalui metode hand sign kodaly pada siswa tunarungu, (2) Langkah - langkah pembelajaran musik angklung melalui metode hand Sign Kodaly pada siswa tunarungu, dan (3) 
Perubahan kemampuan pembelajaran metode Hand

Sign Kodaly pada siswa tunarungu.

\section{Penilaian langkah - langkah pembelajaran musik angklung melalui metode hand sign kodaly}

a. Kegaiatan awal

- Siswa didik terbiasa berdoa sebelum dan sesudah melakukan kegiatan, menjalankan ibadah, memberi dan menjawab salam mendapat penilaian sangat baik.

- Memiliki sikap santun, kurang peduli, percaya diri, kurang disiplin dan tanggungjawab mulai meningkat, perlu pendampingan dan pembinaan secara intensif, mendapat penilaian cukup.

b. Kegiatan inti

- Sebagian materi telah dikuasai siswa dengan bentuk memahami, menerapkan, menganalisis, dan mengevaluasi, pengetahuan dan konsep berdasarkan rasa ingin tahunya tentang seni.

- Penguasaan materi pembelajaran cukup baik

- Implementasi pembelajaran cukup baik

- Pemanfaatan media dan sumber belajar dinilai baik

- Interaksi dengan peserta didik dinilai baik

- Penggunaan bahasa yang benar cukup baik

c. Kegiatan penutup

- Membuat evaluasi materi pembelajaran dinilai baik

- Melaksanakan penilaian pembelajaran dinilai baik

- Melakukan refleksi pembelajaran dinilai cukup baik

Berdasarkan penilaian diatas, diketahui bahwa nilai aktivitas pelaksanaan pembelajaran pada siswa tunarungu diperoleh rata rata dinilai cukup baik, perlu penanganan lebih baik lagi, dengan menambah pertemuan $3 \mathrm{kali}$, sesuai dengan kemampuan setiap siswa didik,.

Kegiatan langkah - langkah pembelajaran diatas menyimpulkan bahwa kegiatan belajar mengajar dilakukan dengan kegiatan pengalaman langsung, Sesuai dengan kebutuhan dan minat siswa, memberikan kesempatan pada siswa untuk menggunakan pemikirannya, menghargai perbedaan individu, menggunakan kegiatan bermain sebagai wahana belajar, karena kegiatan tersebut tidak harus membaca tangga nada dan menghafal partitur.

\section{Hasil analisis pembelajaran metode hand sign Kodaly}

Pelaksanaan pembelajaran ditemukan 3 kelompok siswa didik yang dikategorikan sangat baik, baik, dan kurang dalam memahami pembelajaran musik angklung melalui metode hand sign Kodaly yaitu dengan rentang nilai sangat baik $100 \%-80 \%$, baik $80 \%$ - $70 \%$, dan kurang $70 \%$ $60 \%$ dan hasilnya adalah sebagai berikut:

a. Amanda Aurelia Putri, dia adalah siswa didik kelas 7B, kemampuan mengingat simbol dalam metode hand sign Kodaly termasuk kategori sangat baik, sehingga untuk membaca partitur mudah bagi Amanda Aurelia Putri dan kemampuan melaksanakan pembelajaran musik angklung nilainya mencapai $90 \%$ termasuk kedalam kategori A, termasuk ada peningkatan kreatifitas dari pembelajaran dengan metode sebelumnya, karena memakai metode sebelumnya atau dengan metode SIBI dengan nilai $85 \%$.

b. Rifaldi Agustian Nugraha, Rifal adalah kelas $7 \mathrm{~B}$, rasa percaya dirinya tinggi, rasa ingin tahunya tinggi, kemampuan mengingat simbol dalam metode hand sign Kodaly termasuk kategori baik, harus diulang beberapa kali, rifal mampu mengerti tentang simbol - simbol nya, sehingga untuk membaca partitur tidak terlalu sulit bagi Rifal dan kemampuan melaksanakan pembelajaran musik angklung nilainya mencapai $80 \%$ termasuk kedalam kategori A minus, sama seperti metode sebelumnya Rifal mendapat nilai 80 .

c. Arya Bubun Hasbullah, merupakan kelas 8B, dia mampu untuk mengidentifikasi informasi yang diberikan, tetapi pasif dalam melaksanakan tugas yang diberikan, sehingga siswa ini terlihat banyak diam, dalam pelaksanaan memainkan angklung Arya mampu melaksanakannya, mulai dari menggoyangkan angklung sampai membaca partitur, meskipun harus dijelaskan beberapa kali, tapi arya mampu melaksanakannya, proses pembelajaran dilaksanakan dengan baik, nilainya mencapai $80 \%$ termasuk kedalam kategori A minus.

d. Astri Austin, pada saat memainkan angklung dengan metode SIBI Astri mampu memainkannya, astri adalah kelas $8 \mathrm{~B}$, partitur yang dilihatnya yaitu not angka, tetapi pada waktu diberikan metode hand sign Kodaly Astri kesulitan mengingat simbol - simbol yang diberikan, antusias mempelajarinya begitu semangat, percaya dirinya meningkat. nilainya mencapai $80 \%$ termasuk kedalam kategori A minus, sama seperti nilai metode sebelumnya.

e. Baihaqi Charlie Martis, dia sekarang duduk di kelas 8B, sulit untuk berkomunikasi, tidak dapat mengidentifikasi informasi yang diberikan, sulit untuk mengikuti proses pembelajaran, untuk metode hand sign Kodaly tidak mampu mengidentifikasinya, dia hanya bisa melaksanakan pembelajaran angklung 
hanya memakai bahasa isyarat SIBI, kemampunya malah menurut dari metode sebelumnya, dari $75 \%$ dari metode sebelumnya menjadi $60 \%$ setelah memakai metode hand sign Kodaly.

f. Ersa Yunisa, dia adalah kelas 8B, rasa percaya dirinya tinggi, rasa ingin tahunya tinggi, kemampuan mengingat simbol dalam metode hand sign Kodaly termasuk kategori baik, harus diulang beberapa kali, mampu mengerti tentang simbol - simbol nya, sehingga untuk membaca partitur tidak terlalu sulit bagi Ersa, dan kemampuan melaksanakan pembelajaran musik angklung nilainya mencapai $80 \%$ termasuk kedalam kategori A minus, sama seperti metode sebelumnya Ersa mendapat nilai 80.

g. Fitriyani, sulit untuk berkomunikasi, sekarang fitriyani duduk di kelas 9B, tidak dapat mengidentifikasi informasi yang diberikan, sulit untuk mengikuti proses pembelajaran, untuk metode hand sign Kodaly tidak mampu mengidentifikasinya, dia hanya bisa melaksanakan pembelajaran angklung hanya memakai bahasa isyarat SIBI, kemampuanya malah menurut dari metode sebelumnya, dari $75 \%$ dari metode sebelumnya menjadi $60 \%$ setelah memakai metode hand sign Kodaly.

h. Laura Eka Ananda, dia adalah siswa didik kelas 9B, kemampuan mengingat simbol dalam metode hand sign Kodaly termasuk kategori sangat baik, sehingga untuk membaca partitur mudah bagi Laura dan kemampuan melaksanakan pembelajaran musik angklung nilainya mencapai $90 \%$ termasuk kedalam kategori A, termasuk ada peningkatan kreatifitas dari pembelajaran dengan metode sebelumnya, karena memakai metode sebelumnya atau dengan metode SIBI dengan nilai $80 \%$.

i. Mery Zalsabila, dia adalah kelas 9B, rasa percaya dirinya tinggi, rasa ingin tahunya tinggi, kemampuan mengingat simbol dalam metode hand sign Kodaly termasuk kategori baik, harus diulang beberapa kali, mampu mengerti tentang simbol - simbol nya, sehingga untuk membaca partitur tidak terlalu sulit bagi Mery dan kemampuan melaksanakan pembelajaran musik angklung nilainya mencapai $80 \%$ termasuk kedalam kategori A minus, sama seperti metode sebelumnya Mery mendapat nilai 80 .

j. Ade Sugianto, duduk di kelas 10B-1, sulit untuk berkomunikasi, tidak dapat mengidentifikasi informasi yang diberikan, sulit untuk mengikuti proses pembelajaran, untuk metode hand sign Kodaly tidak mampu mengidentifikasinya, dia hanya bisa melaksanakan pembelajaran angklung hanya memakai bahasa isyarat SIBI, kemampuanya malah menurut dari metode sebelumnya, dari $75 \%$ dari metode sebelumnya menjadi $65 \%$ setelah memakai metode hand sign Kodaly.

k. Indra Aris Sandy, dia sekarang kelas 10 B-1, mampu mengidentifikasi informasi yang diberikan, mampu untuk membaca partitur, mampu memainkan angklung dengan metode hand sign Kodaly, kemampuan sebelumnya mencapai nilai $80 \%$, dan tidak ada kesulitan ketika mengikuti proses pembelajaran sehingga Indra mendapat penilaian $80 \%$, termasuk kategori sangat baik dengan peringkat $\mathrm{A}$.

1. Meli Meliani, sekarang kelas 10 B-1, mampu mengidentifikasi informasi yang diberikan, mampu untuk membaca partitur, mampu memainkan angklung dengan metode hand sign Kodaly, kemampuan sebelumnya mencapai nilai $80 \%$, dan tidak ada kesulitan ketika mengikuti proses pembelajaran sehingga Meli mendapat penilaian $80 \%$, termasuk kategori sangat baik dengan peringkat $A$.

m. Aliffi Ajeng kumala, kelas 10 B-2, mampu mengidentifikasi informasi yang diberikan, mampu untuk membaca partitur, mampu memainkan angklung dengan metode hand sign Kodaly, kemampuan sebelumnya mencapai nilai $90 \%$, dan tidak ada kesulitan ketika mengikuti proses pembelajaran sehingga Aliffi mendapat penilaian $90 \%$, termasuk kategori sangat baik dengan peringkat $\mathrm{A}$.

n. Elfandio Grahmatiar, dia sekarang kelas $10 \mathrm{~B}-$ 2, sulit untuk berkomunikasi, tidak dapat mengidentifikasi informasi yang diberikan, sulit untuk mengikuti proses pembelajaran, untuk metode hand sign Kodaly tidak mampu mengidentifikasinya, dia hanya bisa melaksanakan pembelajaran angklung hanya memakai bahasa isyarat SIBI, kemampunya malah menurut dari metode sebelumnya, dari $70 \%$ dari metode sebelumnya menjadi $60 \%$ setelah memakai metode hand sign Kodaly.

o. Eli Yuliani, merupakan kelas 10 B-2, mampu mengidentifikasi informasi yang diberikan, mampu untuk membaca partitur, mampu memainkan angklung dengan metode hand sign Kodaly, kemampuan sebelumnya mencapai nilai $80 \%$, dan tidak ada kesulitan ketika mengikuti proses pembelajaran sehingga Eli mendapat penilaian $85 \%$, termasuk kategori sangat baik dengan peringkat $A$.

p. Algiat Putradia Sukmayadi, sekarang duduk di kelas $11 \mathrm{~B}$, mampu mengidentifikasi informasi yang diberikan, mampu untuk membaca partitur, mampu memainkan angklung dengan metode hand sign Kodaly, kemampuan sebelumnya mencapai nilai $80 \%$, dan tidak ada 
kesulitan ketika mengikuti proses pembelajaran sehingga Algiat mendapat penilaian $80 \%$ juga, termasuk kategori sangat baik dengan peringkat A.

q. Dilia Bunga Anggraini,dia adalah siswa didik kelas $11 \mathrm{~B}$, kemampuan mengingat simbol dalam metode hand sign Kodaly termasuk kategori sangat baik, sehingga untuk membaca partitur mudah bagi Dila dan kemampuan melaksanakan pembelajaran musik angklung nilainya mencapai $90 \%$ termasuk kedalam kategori A, termasuk ada peningkatan kreatifitas dari pembelajaran dengan metode sebelumnya, karena memakai metode sebelumnya atau dengan metode SIBI dengan nilai $85 \%$.

r. Asep Ruswandi, dia adalah kelas 12 B, rasa percaya dirinya tinggi, rasa ingin tahunya tinggi, kemampuan mengingat simbol dalam metode hand sign Kodaly termasuk kategori baik, harus diulang beberapa kali, mampu mengerti tentang simbol - simbol nya, sehingga untuk membaca partitur tidak terlalu sulit bagi Asep, dan kemampuan melaksanakan pembelajaran musik angklung nilainya mencapai $80 \%$ termasuk kedalam kategori A minus, sama seperti metode sebelumnya Asep mendapat nilai 80 .

s. Neno Alimudin, Neno sekarang kelas 11 B, rasa percaya dirinya tinggi, rasa ingin tahunya tinggi, kemampuan mengingat simbol dalam metode hand sign Kodaly termasuk kategori baik, harus diulang beberapa kali, tapi mampu mengerti tentang simbol - simbol nya, sehingga untuk membaca partitur tidak terlalu sulit bagi Neno, dan kemampuan melaksanakan pembelajaran musik angklung nilainya mencapai $85 \%$ termasuk kedalam kategori A minus, sama seperti metode sebelumnya Asep mendapat nilai $85 \%$.

t. Hani Rahmayanti dia adalah siswa didik kelas

$12 \mathrm{~B}$, kemampuan mengingat simbol dalam metode hand sign Kodaly termasuk kategori sangat baik, sehingga untuk membaca partitur mudah bagi Hani dan kemampuan melaksanakan pembelajaran musik angklung nilainya mencapai $90 \%$ termasuk kedalam kategori A, termasuk ada peningkatan kreatifitas dari pembelajaran dengan metode sebelumnya, karena memakai metode sebelumnya atau dengan metode SIBI dengan nilai $75 \%$.

Berdasarkan hasil analisis pembelajaran musik angklung melalui metode hand sign Kodaly, ternyata efektif diterapkan di sekolah luar biasa negeri Ciamis, dengan penilaian siswa didik sangat baik yaitu $50 \%$ atau 10 orang siswa, siswa didik baik $30 \%$ atau 5 orang siswa, siswa didik cukup
$20 \%$ atau 4 orang siswa, dan siswa didik kurang yaitu $10 \%$ atau 1 orang siswa. Data yang diperoleh dari penelitian ini selain keefektifan metode juga penulis melihat kemampuan guru dalam menyampaikan metode pembelajaran, data tersebut diambil dari pengamatan setiap pertemuan di kelas yang diadakan dalam 4 pertemuan.

\section{SIMPULAN}

Berdasarkan penelitian yang dilakukan mengenai pembelajaran musik angklung melalui metode hand sign Kodaly pada siswa tunarungu di SLB Negeri Ciamis. Disimpulkan masalahnya terkait dengan pertanyaan penelitian yaitu sebagai berikut :

Metode pembelajaran yang digunakan guru dalam menyampaikan materi musik angklung pada siswa tunarungu yaitu diantaranya dengan metode menggunakan sistem isyarat bahasa Indonesia (SIBI) dan metode hand sign Kodaly. Adapun pemilihan metode tersebut disesuaikan dengan karakteristik dan tingkat perkembangan siswa tunarungu. Setiap metode yang digunakan memiliki kelebihan dan kekurangannya masing - masing. mengingat hal tersebut, peran guru sangat diperlukan untuk membangun suasana pembelajaran yang baik, kondusif dan menyenangkan bagi siswa sehingga diharapkan tujuan pembelajaran dapat dicapai dengan optimal.

Rencana pelaksanaan pembelajaran musik angklung melalui metode hand sign Kodaly sudah memenuhi kriteria rencana pelaksanaan pembelajaran berdasarkan kurikulum 2013 yang harus memuat komponen - komponen yaitu: (1) perumusan kompetensi inti, (2) perumusan kompetensi dasar, (3) perumusan indikator pembelajaran, (4) perumusan materi pembelajaran, (5) perumusan metode pembelajaran, (6) perumusan langkah langkah pembelajaran, (7) perumusan alat bahan dan sumber pembelajaran, (8) perumusan penilaian pembelajaran.

Langkah - langkah pembelajaran musik angklung melalui metode hand sign Kodaly meliputi: (1) kegiatan awal, (2) kegiatan inti, (3) kegiatan akhir. Adapun langkah - langkah pembelajaran yang dimaksud adalah sebagai berikut

\section{a. Kegiatan awal}

Membuka dengan salam kemudian berdoa, peserta didik merespon salam tanda mensyukuri anugerah Tuhan dan saling mendoakan. (2)Mengkondisikan peserta didik dengan suasana menyenangkan. (3) Apersepsi dengan cara memberikan gambaran awal pada materi yang akan dipelajari hari ini yaitu musik angklung dengan menunjukan beberapa alat angklung. (4)Peserta didik menyimak, mengidentifikasi, alat angklung dan partitur yang disediakan dalam bentuk gambar. 


\section{b. Kegiatan inti}

Langkah - langkah dalam kegiatan inti meliputi langkah - langkah pembelajaran musik angklung melalui metode hand sign kodaly yang terdiri dari: (1) Mengamati, Siswa mengamati partitur lagu, (2) Menanya, Guru menanyakan kepada siswa tentang "apakah partitur yang diberikan dapat dimengerti dan dibaca? (3) Menalar, Guru menjelaskan tujuan dari membaca partitur yang ingin dicapai siswa, guru memberikan arahan cara membaca partitur yang harus dibaca, guru menentukan tugas - tugas yang harus dilaksanakan setelah bisa membaca partitur. (4) Mengasosiasi, Setiap peserta didik menginterpretasikan tugasnya masing - masing, dan (5) Mengkomunikasikan, Peserta didik secara bergiliran mencoba memainkan angklung yang dipegangnya.

c. Kegiatan akhir

Waktu yang disediakan kurang lebih 20 menit. Meliputi: pemberian tugas dan memberi kesimpulan dan pengamatan.

Perubahan kemampuan siswa Berdasarkan hasil analisis pembelajaran musik angklung melalui metode hand sign Kodaly, ternyata efektif diterapkan di sekolah luar biasa negeri Ciamis, dengan penilaian siswa didik sangat baik yaitu $50 \%$ atau 10 orang siswa, siswa didik baik $30 \%$ atau 5 orang siswa, siswa didik cukup $20 \%$ atau 4 orang siswa, dan siswa didik kurang yaitu $10 \%$ atau 1 orang siswa. Data yang diperoleh dari penelitian ini selain keefektifan metode juga penulis melihat kemampuan guru dalam menyampaikan metode pembelajaran, data tersebut diambil dari pengamatan setiap pertemuan di kelas yang diadakan dalam 4 pertemuan.

Implikasinya dalam kegiatan pembelajaran musik angklung pada siswa yaitu: siswa dapat meningkatkan kemampuan menstimulus minat dan bakat dalam bentuk pengetahuan pembembelajaran seni, siswa dapat meningkatkan kreativitas melalui kegiatan praktek alat musik, siswa memiliki kecintaan terhadap musik angklung.

\section{DAFTAR PUSTAKA}

Budiwati, D. S. dan Milyawati, R. (2011). Belajar dan Pembelajaran Seni Musik. Bandung: CV bintang Warli Artika.

Depdiknas. (2007). Kamus Besar Bahasa Indonesia Edisi Ketiga. Jakarta: Balai Pustaka.

Depdikbud. (1998), Pedoman Pendidikan Kesenian: Panduan Teknik Sebagai Pelengkap Penataran Pendidikan Kesenian bagi Guru Taman Kanak Kanak dan Guru Sekolah Dasar. Jakarta: Dinas Kebudayaan.

Ginting. Abdorakhman. (2008). Esensi Praktis Belajar dan Pembelajaran. Bandung: Humaniora.
Trianto. (2010). Model Pembelajaran Terpadu. Jakarta: PT Bumi Aksara

Sukardi, Alek, dan Sulistiowati, Sri, (2010), Teori dan Praktek Bermain Angklung. Jakarta: PT. Gramedia Widiasarana Indonesia.

Joni, R.T. (1996). Pembelajaran Terpadu D-II PGSD dan S-2 Pendidikan Dasar. Jakarta: Depdikbud.

Pekerti. Widia. (2007). Metode Pengembangan Seni. Jakarta :Universitas Terbuka.

Pamandhi. Hajar (2009) Pendidikan Seni di SD. Jakarta: Universitas Terbuka.

Rianto. Yatim (2010) Paradigma Baru Pembelajaran. Jakarta: Kencana Prenada Media Grup.

Sujana, N. (1998). Dasar dasar Proses Belajar Mengajar. Bandung: Sinar Baru.

Sugiyono. (2012). Metode Penelitian Pendidikan Pendekatan Kualitatif, kuantitatif, dan $R \& D$. Bandung: ALFABETA CV. 